\title{
Cornea engineering on polyester carriers
}

\author{
P. Zorlutuna, ${ }^{1}$ A. Tezcaner, ${ }^{2}$ I. Kiyat, ${ }^{3}$ A. Aydinl1, ${ }^{3}$ V. Hasirci ${ }^{1}$ \\ ${ }^{1}$ Department of Biological Sciences, Biotechnology Research Unit, Middle East Technical University, \\ Ankara 06531, Turkey \\ ${ }^{2}$ Department of Engineering Sciences, Middle East Technical University, Ankara 06531, Turkey \\ ${ }^{3}$ Department of Physics, Bilkent University, Ankara 06800, Turkey
}

Received 3 August 2005; revised 16 January 2006; accepted 9 February 2006

Published online 6 June 2006 in Wiley InterScience (www.interscience.wiley.com). DOI: 10.1002/jbm.a.30772

\begin{abstract}
In this study, biodegradable polyester based carriers were designed for tissue engineering of the epithelial and the stromal layers of the cornea, and the final construct was tested in vitro. In the construction of the epithelial layer, micropatterned films were prepared from blends of biodegradable and biocompatible polyesters of natural (PHBV) and synthetic $(\mathrm{P}(\mathrm{L} / \mathrm{DL}) \mathrm{LA})$ origin, and these films were seeded with D407 (retinal pigment epithelial) cells. To improve cell adhesion and growth, the films were coated with fibronectin. To serve as the stromal layer of the cornea, highly porous foams of $\mathrm{P}(\mathrm{L} / \mathrm{DL}) \mathrm{LA}-\mathrm{PHBV}$ blends were seeded with 3 T3 fibroblasts. Cell numbers on the polyester carriers were significantly higher than those on the tissue culture polystyrene control. The cells and the carriers were characterized scanning electron micrographs showed that the foam was highly porous and the pores were interconnected. 3T3 Fibroblasts were distributed quite homoge-
\end{abstract}

neously at the seeding site, but probably because of the high thickness of the carrier $(\sim 6 \mathrm{~mm})$; they could not sufficiently populate the core (central parts of the foam) during the test duration. The D407 cells formed multilayers on the micropatterned polyester film. Immunohistochemical studies showed that the cells retained their phenotype during culturing; D407 cells formed tight junctions characteristic of epithelial cells, and 3T3 cells deposited collagen type I into the foams. On the basis of these results, we concluded that the micropatterned films and the foams made of $\mathrm{P}(\mathrm{L} /$ DL)LA-PHBV blends have a serious potential as tissue engineering carriers for the reconstruction of the epithelial and stromal layers of the cornea. (c) 2006 Wiley Periodicals, Inc. J Biomed Mater Res 79A: 104-113, 2006

Key words: cornea; tissue engineering; polyester; retinal pigment epithelial cells; fibroblasts

\section{INTRODUCTION}

Cornea is the outermost layer of the eye and corneal damages constitute $\sim 37 \%$ of all visual disabilities and $23 \%$ of medical visits for ocular problems in North America. ${ }^{1}$ In this in vitro study, we aimed to construct the top two layers of the cornea, the epithelial and stromal layers, using biodegradable polymeric carriers which were seeded with retinal pigment epithelial cells and fibroblasts.

Cornea is $\sim 500 \mu \mathrm{m}$ in thickness. ${ }^{2}$ It is transparent even though the corneal tissue consists of a highly organized group of cells and extracellular matrix (ECM). The key factor in its transparency appears to

Correspondence to: V. Hasırc1; e-mail: vhasirci@metu.edu.tr Contract grant sponsor: European Union FP6 STREP

Project Cornea Engineering; contract grant number: 504017

Contract grant sponsor: Middle East Technical University Scientific Research Projects; contract grant numbers: BAP 2004-07-02-00-16 and BAP 2005-01-08-02

Contract grant sponsor: TUBITAK TBAG 2288

(C) 2006 Wiley Periodicals, Inc. be the unique composition and organization of its ECM where the collagen fibers have a highly regular arrangement. ${ }^{3-5}$ They alternate as orthogonally oriented lamella especially in the central and posterior stroma. The proteoglycans (keratan sulfate, chondroitin sulfate, and dermatan sulfate) of the ECM also participate in this regular arrangement. ${ }^{6}$

Damages to the cornea can be limited to the epithelium (such as in uncomplicated erosion) or could involve the epithelial basement membrane, the stromal lamella, and even the endothelium (the inner most layer). These damages can be caused by injuries due to foreign materials and chemical burns or due to viral or bacterial infections. ${ }^{1}$ Despite currently available treatments, corneal scar tissue formation occurs in many of these cases. This is a very severe problem that leads to loss of transparency of the cornea and eventually to blindness. In such cases, replacement of cornea is necessary. The current corneal replacements include donor and artificial corneas. Cornea is the most widely transplanted tissue and more than 50,000 corneal transplantations are performed each year in the 
TABLE I

Dimensions and Geometry of Micropatterned Templates

\begin{tabular}{|c|c|c|c|c|}
\hline Template & Geometry of Template & $\begin{array}{l}\text { Groove Width } \\
\qquad(\mu \mathrm{m})\end{array}$ & $\begin{array}{l}\text { Ridge Width } \\
\qquad(\mu \mathrm{m})\end{array}$ & $\begin{array}{c}\text { Groove Depth } \\
(\mu \mathrm{m})\end{array}$ \\
\hline A3 & V-shaped parallel channels & 2 & 10 & 30 \\
\hline $\mathrm{C} 3$ & V-shaped parallel channels & 2 & 10 & 20 \\
\hline D1 & Alternating square pits $(10 \times 10$ and $20 \times 20)$ & 4 & $20 / 10$ & 1 \\
\hline
\end{tabular}

United States and Eastern Europe. ${ }^{7}$ Corneal transplants are considered to be the most successful transplants with a rejection rate of $10 \% .{ }^{8}$ On the other hand, the development of artificial corneas made of synthetic polymers such as poly(2-hydroxyethyl methacrylate) have been developed for many years, but they still have drawbacks such as mechanical weakness and calcium deposition. ${ }^{9-11}$ Besides, these polymeric corneas do not carry viable elements. Even though there is a $10 \%$ risk of failure and there is a serious donor shortage transplantation is still the preferred treatment. Artificial corneas are used only when corneal transplantation is not an option. ${ }^{12}$

In recent years, the field of biomaterials developed in a new direction called tissue engineering, which involves use of cells together with biodegradable carriers. Currently, research on corneal treatments is intensified on tissue engineering, and it will be a very important solution to the very serious problem of corneal damages. ${ }^{13-16}$

In tissue engineering, polymers are used as temporary carriers for the cells. Polyesters are among the most widely investigated polymers. Polyhydoxyalkanoates (PHA), which are natural polyesters, are produced by microorganisms and they are biodegradable and biocompatible. Poly(hydroxybutyric acid-co-3-hydroxyvaleric acid) (PHBV) is one of the copolymers of PHA. PHBV is known to be not toxic to cells and a good substrate for cell adhesion and proliferation. ${ }^{17}$ Poly(L-lactide-co-D,L-lactide) (P(L/DL)LA (70/30)) is a synthetic polymer among the polymer family of poly $(\alpha$-hydroxy esters), which is a widely investigated and used family in biomaterial applications. P(L/ DL)LA is also a biodegradable and biocompatible polymer. $\mathrm{P}(\mathrm{L} / \mathrm{DL}) \mathrm{LA}$ is a faster degrading polymer when compared to PHBV and it begins to degrade in a few weeks. It takes much longer for PHBV; degradation could last as long as 53 weeks. ${ }^{18}$

In this study, a unique blend of biodegradable and biocompatible polymers (P(L/DL)LA and PHBV were designed as $2 \mathrm{D}$ and $3 \mathrm{D}$ carriers for the reconstruction of epithelium and the stroma of the cornea. The 2D carriers were films with micropatterns, and were tested in vitro with D407 retinal pigment epithelial cells. The 3D carriers were foams and were seeded with 3 T3 fibroblasts, and their physical properties and compatibility with the cells were studied. The results indicate that the carriers designed permit cell prolif- eration and functionality; therefore, they could be used as carriers for the tissue engineering of the cornea after further developments.

\section{MATERIALS AND METHODS}

\section{Materials}

Poly(3-hydroxybutyric acid-co-3-hydroxyvaleric acid) (PHBV, HV content $8 \% \mathrm{w} / \mathrm{w}$ ) was purchased from Aldrich Chemical Company. Poly(L-lactide-co-D,L-lactide) (P(L/ DL)LA (70/30), Resomer® LR 708, molar ratio L-lactide:D,Llactide 70:30) was supplied by Boehringer-Ingelheim (Germany). Fetal bovine serum (FBS) was obtained from Biochrome KG (Germany). Dulbecco's Modified Eagle Medium (DMEM) was obtained from Gibco Invitrogen (New Zealand). MTS kit was purchased from Promega. Cacodylic acid sodium salt, ascorbic acid, glutaraldehyde (Grade I, $25 \%$ aqueous solution), trypsin-EDTA $(0.25 \%)$, sodium azide, and monoclonal anti-pan cytokeratin (mixture clones C-11, PCK-26, CY-90, KS-1A3, M20, A53-B/A2, mouse ascites fluid) were supplied by Sigma Chemical. Mouse antiZO-1 was purchased from Zymed Laboratories. Tween 20, formaldehyde (37\%), dichloromethane (DCM), and dioxane were obtained from Merck (Germany). Fibronectin (FN pure, from human plasma) was purchased from Roche Diagnostics (Germany). AlexaFluor 488 was supplied by Molecular Probes. Triton X-100 was purchased from Applichem $\mathrm{GmbH}$ (Germany). Bovine serum albumin (BSA) was supplied by Fluka (Germany). Acridine Orange was obtained from BDH Chemicals (UK). The RPE cell line D407 was a kind gift of Dr. R. Hunt (Department of Ophthalmology, University of South Carolina Medical School, USA). 3T3 cell line was purchased from Foot-and-Mouth Disease Institute of Ministry of Agriculture and Rural Affairs (Turkey).

\section{Methods}

Preparation of carriers

\section{Preparation of templates and micropatterned films}

Micropatterned silicon templates with different dimensions and geometries (Table I) were produced by photolithography and subsequent chemical etching. PHBV and $\mathrm{P}(\mathrm{L} / \mathrm{DL}) \mathrm{LA}$ were dissolved in DCM and then cast over the 
template to produce micropatterned films with pattern dimensions opposite to those of the template. Thus, two types of films with $2 \mu \mathrm{m}$ ridge width and $10 \mu \mathrm{m}$ groove width and 20 or $30 \mu \mathrm{m}$ depths were obtained. The third film type was produced with square pits with 10 and $20 \mu \mathrm{m}$ sides and a 1 $\mu \mathrm{m}$ depth.

\section{Preparation of foams}

P(L/DL)LA-PHBV $(1: 1 \mathrm{w} / \mathrm{w})$ in dioxane $(4 \%, 45 \mathrm{~mL})$ was poured into glass Petri dishes, maintained at $-20^{\circ} \mathrm{C}$ overnight, and freeze-dried (FreeZone ${ }^{\circledR} 6$ Liter Freeze Dry System, Labconco Corporation) for $16 \mathrm{~h}$.

\section{Fibronectin coating of polyester films and foams}

The $\mathrm{P}(\mathrm{L} / \mathrm{DL}) \mathrm{LA}-\mathrm{PHBV}$ films were coated with fibronectin by incubating in fibronectin solution for $10 \mathrm{~min}(50 \mu \mathrm{g} / \mathrm{mL}$ fibronectin in PBS). At the end of $10 \mathrm{~min}$, the films were washed with PBS to remove excess fibronectin and dried under sterile conditions in a laminar flow (LaminAir Safe 2000, Holten A/S, Denmark). Foams were coated with fibronectin by incubating overnight, then washed, and stored in PBS until cell seeding.

\section{Characterization of carriers}

\section{Physical characterization}

Foam density was measured by using a pycnometer $(n=$ 2). ${ }^{17}$ The thickness of the films and foams were measured by a micrometer with a $0.001 \mathrm{~mm}$ sensitivity $(n=6)$.

\section{Microscopic characterization}

The topography of the carriers was studied using a scanning electron microscope (SEM) (JSM 6400, JEOL, Japan) after coating with a thin film of gold under vacuum.

The cross-section of the foams was examined under a light microscope (IX 70, Olympus, Japan) after taking 4 or $10 \mu \mathrm{m}$ thick sections in frozen state by using a microtome (CM 1510, Leica, Germany).

\section{Cell culture studies}

D407 cells (passages 5-15) were used to serve as epithelial cells and 3T3 cells (passages 5-15) were used in place of stromal cells. They were cultivated in high glucose DMEM supplemented with 5\% FBS, 100 units $/ \mathrm{mL}$ penicillin, and 100 units $/ \mathrm{mL}$ streptomycin in a carbon dioxide incubator $\left(37^{\circ} \mathrm{C}, 5 \% \mathrm{CO}_{2}, \mathrm{MCO}-17 \mathrm{AIC}\right.$, Sanyo Electric, Japan). The cells were passaged using $0.05 \%$ trypsin-EDTA solution.

\section{Cell seeding onto carriers}

\section{$2 D$ micropatterned films.}

In the cell seeding tests with D407 cells films were used with fibronectin treatment, while others were used as is. $\mathrm{P}(\mathrm{L} / \mathrm{DL}) \mathrm{LA}-\mathrm{PHBV} 8$ films were sterilized by immersing in sterile $\mathrm{EtOH}(70 \%)$ for $2 \mathrm{~h}$ at $4^{\circ} \mathrm{C}$ and washed four times with PBS. D407 cells were detached from the tissue culture flasks by using $0.05 \%$ trypsin for $5 \mathrm{~min}$ at $37^{\circ} \mathrm{C}$, then centrifuged for $5 \mathrm{~min}$ at $3000 \mathrm{rpm}$, and resuspended in high glucose DMEM supplemented with 5\% FBS, 100 units $/ \mathrm{mL}$ penicillin, and 100 units $/ \mathrm{mL}$ streptomycin. Cell number was counted using NucleoCounter (ChemoMetec A/S, Denmark). Twenty microliters cell suspension containing $5 \times$ $10^{4}$ cells were seeded on each film and the films were not disturbed for $30 \mathrm{~min}$ to allow cell attachment. After $30 \mathrm{~min}$, $500 \mu \mathrm{L}$ high glucose DMEM supplemented with 5\% FBS, 100 units $/ \mathrm{mL}$ penicillin, and 100 units $/ \mathrm{mL}$ streptomycin were added. They were incubated in a $\mathrm{CO}_{2}$ incubator $\left(5 \% \mathrm{CO}_{2}\right.$, $37^{\circ} \mathrm{C}$ ) for 14 days. The medium was refreshed every day. Tissue culture polystyrene (TCPS) was used as the control because of its optimal properties for cell cultivation.

$3 D$ foams.

$\mathrm{P}(\mathrm{L} / \mathrm{DL}) \mathrm{LA}-\mathrm{PHBV}$ foams were sterilized by immersing in sterile $\mathrm{EtOH}(70 \%)$ for $2 \mathrm{~h}$ at $4^{\circ} \mathrm{C}$ and washed four times with PBS. The 3T3 cells were detached as described for D407 cells and cell number was counted in the NucleoCounter. Two different seeding densities were used; $5 \times 10^{5}$ cells $/ 75 \mu \mathrm{L}$ or $2.5 \times 10^{5}$ cells $/ 75 \mu \mathrm{L}$ were seeded on each foam, and the foams were not disturbed for $45 \mathrm{~min}$ to allow cell attachment. Then, $500 \mu \mathrm{L}$ high glucose DMEM with 5\% FBS, 100 units $/ \mathrm{mL}$ penicillin, and 100 units $/ \mathrm{mL}$ streptomycin were added. They were incubated in a $\mathrm{CO}_{2}$ incubator $\left(5 \% \mathrm{CO}_{2}\right.$, $37^{\circ} \mathrm{C}$ ) for 14 days. The medium was refreshed every day. After 7 days of incubation, the number of daily medium changes per day was increased to 2. TCPS was used as control.

\section{Characterization of cell seeded carriers}

\section{Cell proliferation.}

In the determination of cell number, the kit: CellTiter $96 \AA$ $\mathrm{AQ}_{\text {ueous }}$ Non-Radioactive Cell Proliferation Assay (Bulletin TB169) of Promega (Madison, WI) was used $(n=3) .{ }^{19}$

Morphology of cells.

Before observation with SEM and fluorescence microscopy (IX 70, Olympus, Japan), the D407 and 3T3 cells were fixed with glutaraldehyde $(2.5 \%)$ for $2 \mathrm{~h}$ and washed twice with cacodylate buffer $(0.1 M, \mathrm{pH} 7.4)$. Specimens for SEM were freeze-dried for $8 \mathrm{~h}$ and then examined after coating with gold. The samples for fluorescence microscopy were stained with Acridine orange, after washing with $\mathrm{HCl}$ $(0.1 \mathrm{M})$ for $1 \mathrm{~min}$. After $15 \mathrm{~min}$, Acridine orange was removed and the sample was washed with distilled water. Foams were sectioned ( $5 \mu \mathrm{m}$ thick) by using a microtome. The cells were observed under the fluorescence microscope at the excitation wavelength of $480 \mathrm{~nm}$ or under confocal microscope (LSM510, Zeiss, Germany) at $488 \mathrm{~nm}$.

Immunohistochemical studies.

For immunohistochemical analysis, fixation was done with formaldehyde (4\%) for $30 \mathrm{~min}$, and samples were 

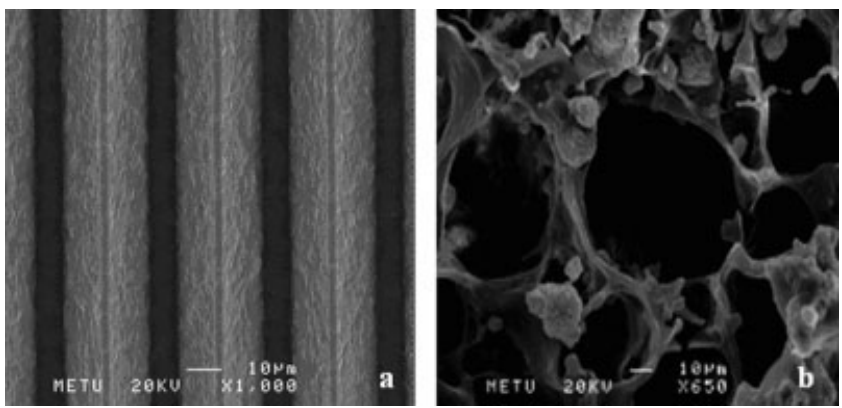

Figure 1. The SEM micrographs of $2 \mathrm{D}$ and $3 \mathrm{D} P(\mathrm{~L} / \mathrm{DL}) \mathrm{LA}-$ PHBV cell carriers. (a) Patterned film $(\times 1000)$ and (b) foam (×650).

washed twice with PBS. The cells were permeabilized by Triton X-100 (0.1\%) treatment (5 min) and washed four times with PBS. The samples were then transferred to blocking solution (0.5\% BSA, 0.1\% Tween 20, 0.1\% FBS, 0.1\% sodium azide in PBS) for $30 \mathrm{~min}$. Primary antibodies $(250 \mu \mathrm{L})$ mouse anti ZO-1 (15 (g/mL in blocking solution) or Anti-Pan cytokeratin (diluted 200-fold in blocking solution) was pipetted onto the samples and incubated at $4^{\circ} \mathrm{C}$ overnight. They were incubated with secondary antibody (Alexaflour 488, $300 \mu \mathrm{L}$ diluted 400 -fold in blocking solution) for $1 \mathrm{~h}$ at $37^{\circ} \mathrm{C}$, washed three times with PBS and examined under the fluorescence microscope at the excitation wavelength of $480 \mathrm{~nm}$.

\section{RESULTS AND DISCUSSION}

\section{Physical and microscopic characterization of films and foams}

In this study biodegradable, polymeric cell carriers of 2D (films with different micropatterns) and 3D (foams) form were designed. The carriers were characterized before testing in vitro.

\section{Physical characteriztion}

The density of P(L/DL)LA-PHBV foams was calculated as $0.11 \pm 0.03 \mathrm{~g} / \mathrm{mL}$ by using a pycnometer $(n=$ 2 ), and is consistent with previous studies with PHBV foams. ${ }^{17}$ This low density shows that the foam has the highly porous structure necessary for use in the construction of a cell carrier. ${ }^{20}$ It is known that pore size, pore shape, and interconnectivity of these pores affect cell growth, ${ }^{21}$ and an ideal 3D cell carrier should be highly porous for the cells to get nutritional elements, discard waste, and also allow sufficient space for proper ECM formation.

The average thickness of the films and foams prepared in this study were measured as $40 \pm 2 \mu \mathrm{m}$ for films and $6.11 \pm 0.08 \mathrm{~mm}$ for foams $(n=6)$.
Microscopical examination

\section{Scanning electron microscope}

Scanning electron microscope (SEM) yields information about the morphology of the carriers. Films prepared on patterned silicon wafers (A3) were smooth and the pattern was regular and sharp [Fig. 1(a)]. The width of the base of the channels is quite close to $10 \mu \mathrm{m}$, and similarly, the ridge width is close to $2 \mu \mathrm{m}$. Foams were highly porous as expected from the density calculations. The pores appeared to be interconnected and pore dimensions were suitable for RPE or fibroblast adhesion and growth [Fig. 1(b)].

\section{Light microscopy}

Sections of foams (4- and 10- $\mu \mathrm{m}$ thick) were obtained by a microtome and examined under light microscope to observe the inner structure, the porosity, and the pore size distribution within the foams. The dark lines in Figure 2(a,b) are polymeric boundaries of the open-celled structure. These micrographs confirm the SEM in that the carrier has a highly porous structure suitable for cell seeding. Even though the magnifications are the same, in $4 \mu \mathrm{m}$ sections, the pore sizes appear to be larger than in the $10 \mu \mathrm{m}$ sections, because in the thicker sections the pores of various depths overlap. As Figure 2(b) reveals the pore sizes are at least $40 \mu \mathrm{m}$ or larger and therefore are larger than the size of the typical cell. The low apparent pore sizes in Figure 2(a) indicate that the pores are not in the form of parallel channels and therefore cells need to follow a tortuous path if they need to move towards the core of the foam.

\section{In vitro studies}

D407 cells on patterned films

RPE cells were tested on the patterned films after adsorption of fibronectin on the surface to improve cell adhesion.

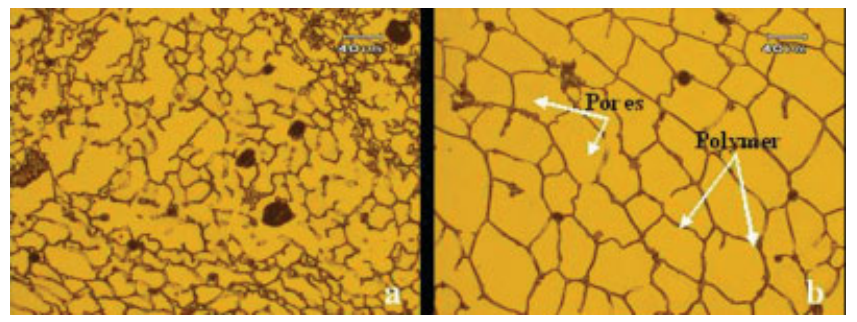

Figure 2. Light microscopy of foams. Sections were taken by a microtome and the section thickness is (a) $10 \mu \mathrm{m}$ and (b) $4 \mu \mathrm{m}(\times 20)$. [Color figure can be viewed in the online issue, which is available at www.interscience.wiley.com.] 


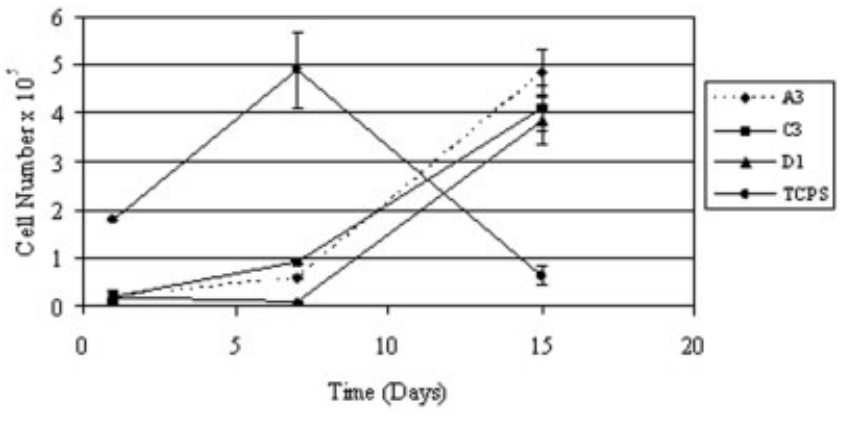

Figure 3. Growth profile of D407 cells on three differrent micropatterned P(L/DL)LA-PHBV films and TCPS (control) $(n=3)$. Initial cell seeding number was $5 \times 10^{4}$.

\section{Cell proliferation without fibronectin}

Cell proliferation was studied by MTS assay as described previously and quantified using an OD versus cell number calibration curve. In this test, three films with different patterns were studied. The TCPS control (unpatterned) had a higher initial cell number than the test samples (Fig. 3). The cell numbers increased further until Day 7 before declining to levels lower than on Day 1 probably because of cell death. On the other hand, there was a lag phase of 7 days with all patterned films and the numbers increased between days 7 and 14. This was probably because initially the cells were not able to attach to and spread on the polymeric surface as good as on the TCPS control. ${ }^{22}$ At the end of the 14th day, however, the cell numbers reached $\left(4.83 \times 10^{5}\right)$ was very close to the maximum value observed with TCPS $\left(4.89 \times 10^{5}\right)$. The maxima for the control and the test samples were practically the same.

The increase in the cell number on TCPS between Day 1 and Day 7 was 3-fold, but the increase was around 20-fold for D1, C3, and A3 patterned films between Days 7 and 14. Thus, a much larger rate of increase in cell number was observed on the patterned films. Similar results have been reported for PLGA films seeded with RPE cells where an increase of 24fold was achieved. ${ }^{23}$ Figure 3 also shows that the pattern type (microchannels or pits) and dimensions (channel depth, ridge width etc.) of the patterns on the films did not affect the growth profile of the cells or the maximum cell number.

It was earlier reported that surface topography affects corneal epithelial stratification. ${ }^{24}$ Moreover, epithelial stratification was enhanced on surfaces with deep grooves. ${ }^{25}$ The A3 pattern was the template with the deepest grooves $(30 \mu \mathrm{m})$, it enhanced the stratification of the epithelial cells and showed the highest increase in cell number, and it was, therefore, selected for use in the rest of the studies where just one film type was tested.
Cell proliferation upon fibronectin adsorption on the film surface

It is known that fibronectin participates in the attachment of corneal epithelial cells on the ECM. Nishida et al. showed that fibronectin coating of culture dishes increased adhesion of corneal epithelial cells in proportion with the fibronectin concentration. $^{26}$ To improve the adhesion on the surface of the films, they were passively and selectively coated with fibronectin.

Unlike the untreated films, almost no lag phase was observed with the fibronectin treated films. This is possibly because fibronectin increased the adhesion of the cells on surface of the films and also improved their spreading, enhancing their proliferation amount and rate. TCPS had a slightly higher more attached cells initially and had a higher cell number on Day 7, and the increase in cell number between Day 1 and 7 was 11 times. With P(L/DL)LA-PHBV films with A3 patterns, this increase was 60-fold. Eventually, both curves leveled off and on Day 14 the cell numbers were almost the same for both the films and the control (Fig. 4).

\section{Microscopical examination of RPE cells on untreated micropatterned films}

D407 cells were seeded on untreated films, and incubated for 14 days at $37^{\circ} \mathrm{C}$ and $5 \% \mathrm{CO}_{2}$ medium. On Days 7 and 14, the cells were stained with Acridine orange for DNA and examined under the fluorescence microscope. On Day 7, D407 cells were low in number and in monolayers on films with the three types of patterns [Fig. 5(a,c,e)]. The ridges of the patterns were visible with the regions in between quite full of cells oriented in the direction of the axis indicating that cell guidance by the physical boundaries (ridges of the channels) was achieved. By Day 14, cells reached confluency and formed multilayers on all films [Fig.

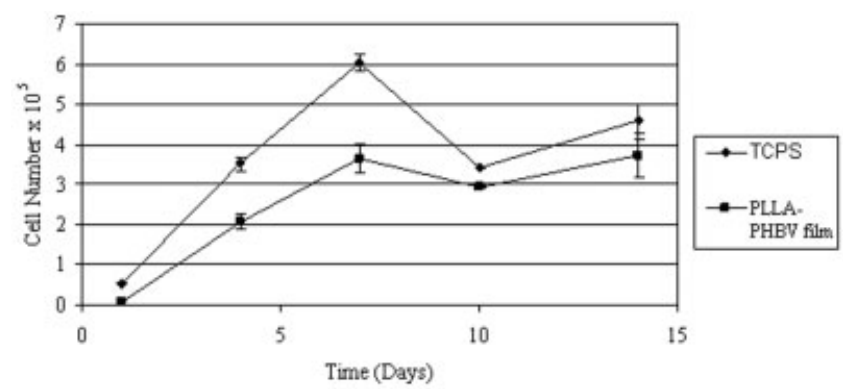

Figure 4. Growth profile of D407 cells on A3 micropatterned, fibronectin coated P(L/DL)LA-PHBV8 film, and TCPS (control) $(n=3)$. Initial cell seeding number was $5 \times$ $10^{4}$. 

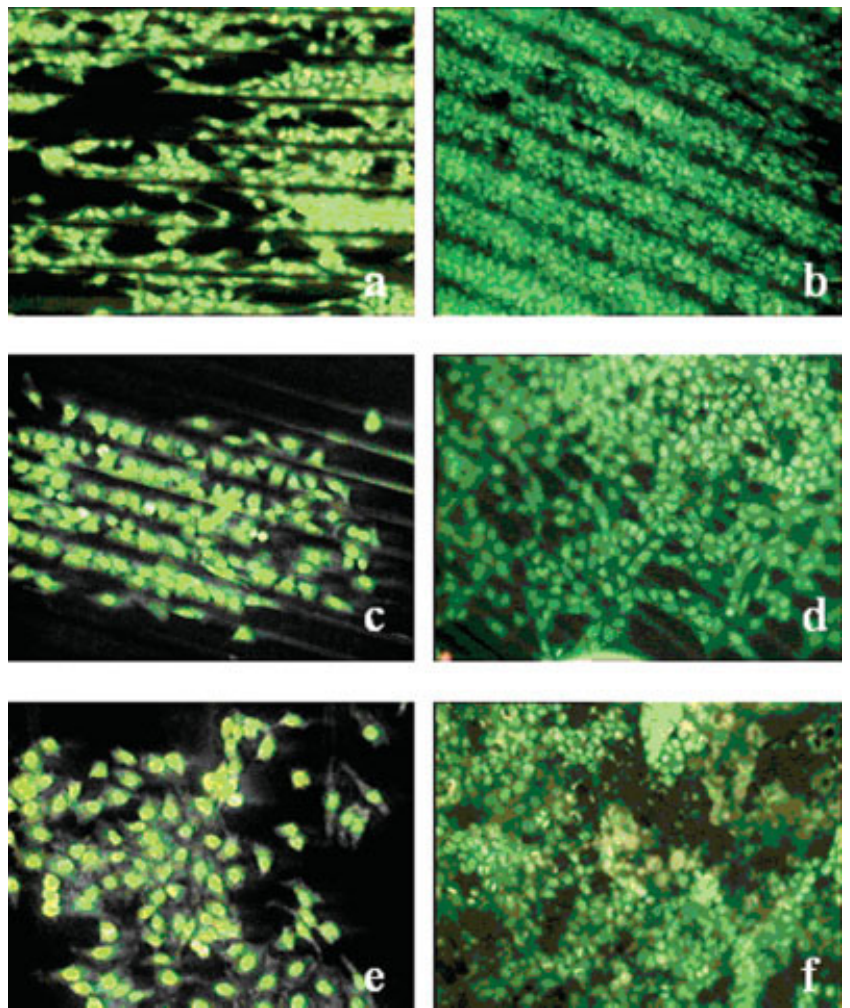

Figure 5. Fluorescence micrographs of D407 cells seeded on the A3, C3, and D1 patterned films, stained with Acridine orange. Observations were made on Day $7(\mathrm{a}, \mathrm{c}, \mathrm{e})$ and Day 14 $(b, d, f)(\times 10)$. [Color figure can be viewed in the online issue, which is available at www.interscience.wiley.com.] $5(\mathrm{~b}, \mathrm{~d}, \mathrm{f})]$ forming a stratified structure similar to epithelial layer in the natural cornea.

On Day 14, cell guidance was visible only on A3 films possibly because A3 had the deepest grooves. Although the cells formed 2, or at some places 3, layers cell guidance inside the grooves was still maintained [Fig. 5(b)].

These results are in parallel with the previous studies which has shown, for both epithelial cells in gen$\mathrm{eral}^{27}$ and specifically for corneal epithelial cells, ${ }^{28}$ that grooved surfaces lead to contact guidance, and therefore, alignment of the cells is observed along the grooves.

Microscopical examination of RPE cells on fibronectin treated films

Fibronectin adsorbed films of A3 design were examined under fluorescence microscope on Days 1, 7, and 14 (Fig. 6). The RPE cells were seeded at the center of the films and their increase in number and spread towards the edges were studied. The result of Day 1 is an important indicator of the affinity of the cells to a surface.

The Day 1 micrographs of A3 films seeded with RPE showed that the cells at the seeding site were attached, spread on the surface, and guided by the pattern [Fig.

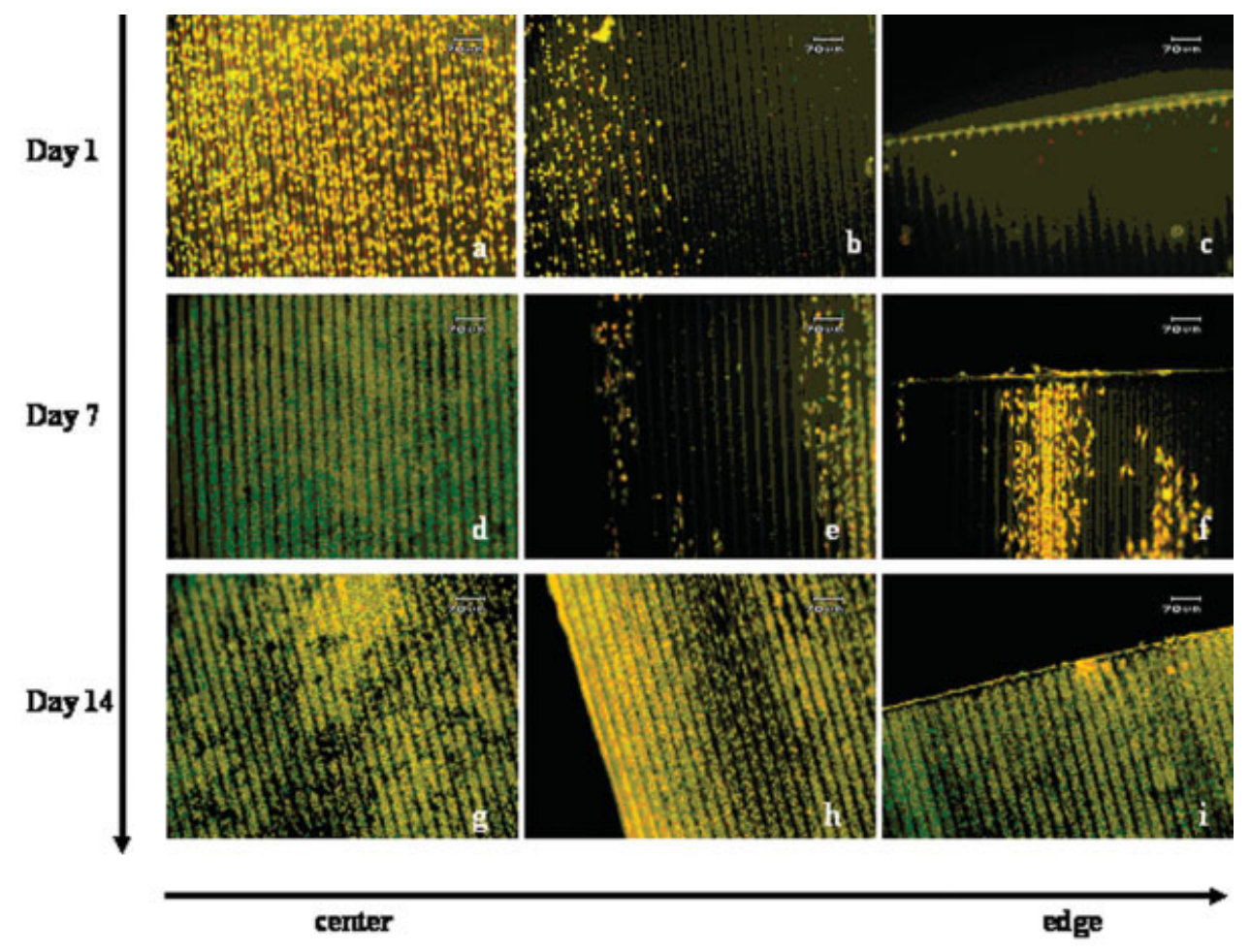

Figure 6. D407 cells on A3 micropatterned, fibronectin coated films, stained with Acridine orange. Day 1 (a-c), Day 7 (d-f), and Day $14(\mathrm{~g}-\mathrm{i}) .(\mathrm{a}),(\mathrm{d})$, and $(\mathrm{g})$ are the micrographs of the initial seeding site, (b), (e), and (h) are towards the edge and (c), (f), and (i) are the edge of the films $(\times 10)$. [Color figure can be viewed in the online issue, which is available at www.interscience.wiley.com.] 

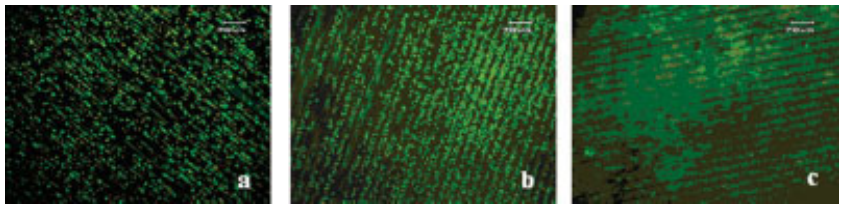

Figure 7. Anti Pan-Cytokeratin staining of D407 cells on A3 micropatterned, fibronectin coated films on (a) Day 1, (b) Day 7 , and (c) Day $14(\times 10)$. [Color figure can be viewed in the online issue, which is available at www.interscience. wiley.com.]

6(a-c)]. This is in contrast to untreated films (Fig. 5) where the surface coverage was not as much. Towards the edges of the film (away from the center, the initial seeding site), the cell number decreased and at the edges there were no cells [Fig. 6(b,c)]. On Day 7, cells started to form multilayers at the initial seeding site [Fig. 6(d)], and proliferated at the edges of the film [Fig. 6(e,f)]. On Day 14, they were confluent on all areas of the film including the edges [Fig. 6(i)] and also formed multilayers on all regions [Fig. 6(g-i)].

\section{Immunohistochemical analysis}

\section{Anti pan-cytokeratin staining.}

Cytokeratins are the lineage markers for epithelial cells and therefore, anti pan-cytokeratin stain labels specifically the epithelial cells such as D407. Staining was done to show that the cells conserved their epithelial character during the 14-day culture period. As can be seen in Figure 7 the D407 cells retained their phenotype for the whole duration of the study.

Anti ZO-1 staining.

$\mathrm{ZO}-1$ is a membrane associated protein and is a component of corneal epithelial tight junction complexes. Tight junction formation by epithelial cells is important because the primary function of epithelial cells is to form a barrier or a layer of protection. In cornea, epithelial layer prevents leakage and regulates passage of molecules in and out of the inner layers of the cornea. ${ }^{29}$ Staining was done to show that D407 cells formed tight junctions, and therefore, the cells were functional (Fig. 8).

It is observed that as the duration increased more of the surface was covered both in 2D and in 3D with anti
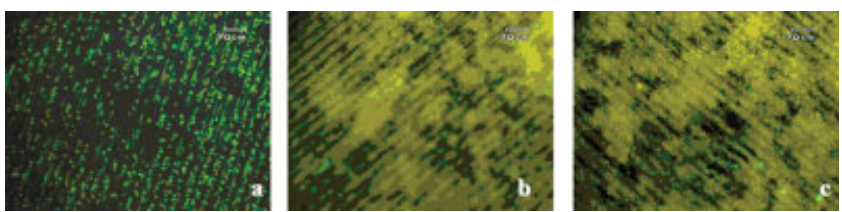

Figure 8. Anti ZO-1 staining of D407 cells on A3 micropatterned, fibronectin coated films on (a) Day 1, (b) Day 7, and (c) Day $14(\times 10)$. [Color figure can be viewed in the online issue, which is available at www.interscience.wiley.com.]

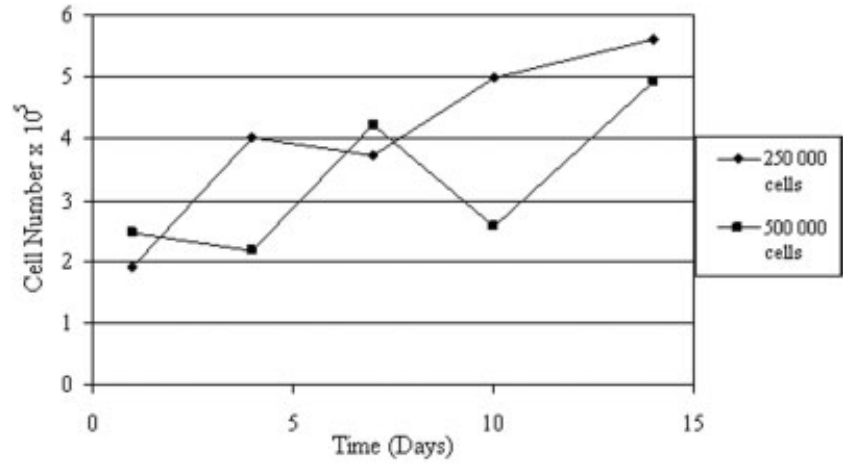

Figure 9. Growth profile of $3 \mathrm{~T} 3$ cells with different initial seeding densities $\left(2.5 \times 10^{5}\right.$ and $\left.5 \times 10^{5}\right)$ on P(L/DL)LAPHBV foams $(n=3)$.

ZO-1 stained cells. It can thus be concluded that the D407 cells retained their phenotype during these experiments.

Foams as cell carriers

P(L/DL)LA-PHBV blends were also tested for their capacity to act as cell carriers in $3 \mathrm{D}$ form. The foams obtained through freeze drying were tested for the fibroblast (3T3) cell proliferation using MTS, SEM, and confocal microscopy.

\section{Cell proliferation}

Two different initial cell seeding densities were used to study 3T3 proliferation and distribution within the foams. Cell proliferation was studied by MTS assay as described previously (Fig. 9).

On polyester foams with initial seeding density of $5 \times 10^{5}$, the cell number was $2.5 \times 10^{5}$ on Day 1 and this did not change for 3 days, and then increased to $5 \times 10^{5}$ on Day 14 . The fluctuations in cell number between Days 1 and 14 were probably caused by the high cell number in the limited space being insufficient for survival, and led the cells to a death phase. This in turn increased the space available, and helped the remaining viable cells to increase in number again.

The cell numbers and the fluctuation in the cell number was higher in TCPS (data not shown) most probably because it was a two dimensional carrier and access to nutritional elements was not as difficult as in a 3D foam. The maximum cell numbers obtained in foams were $4.2 \times 10^{5} \pm 6 \times 10^{4}$ and $4.9 \times 10^{5} \pm 7 \times$ $10^{4}$ cells on Days 7 and 14 , respectively.

The MTS results indicated that initial seeding density of $5 \times 10^{5}$ cells/foam could be too high because the fluctuations were large and cell numbers were low. When the initial seeding density was decreased to $2.5 \times 10^{5}$, the MTS results showed that the degree of 

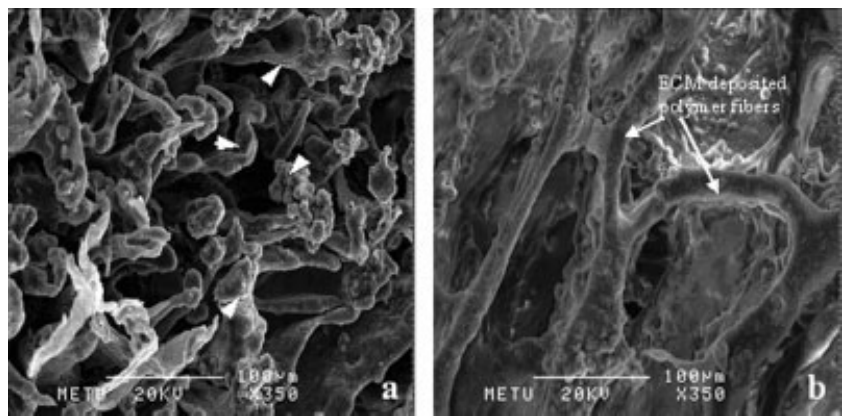

Figure 10. SEM micrographs of the top (initial seeding site) of 3 T3 seeded P(L/DL)LA-PHBV foams on (a) Day 7 and (b) Day 14 ( $\times 350$, arrow heads indicate cells).

fluctuation was less and the cell number reached on Day $14,5.6 \times 10^{5} \pm 2 \times 10^{3}$ was higher than when $5 \times$ $10^{5}$ cells were seeded. The increase in cell number between Days 1 and 14 was significantly higher (3fold) with respect to higher seeding (2-fold) and also with respect to the control (1.5-fold). This is a good result because in a previous study with fibroblasts on 3D collagen carriers, the rate of increase was 1.5-fold in 21 days and there was also fluctuation of cell number on these carriers. ${ }^{30}$ In another study with porous PHBV foams, it was shown that these carriers were more suitable for fibroblast seeding than collagen foams. PHBV foams maintained their integrity in culture conditions and the cells on these foams were twice as functional as the ones on collagen foams as judged by the total protein production in 4 weeks in the cell culture. ${ }^{31}$

\section{Microscopical observations}

\section{Scanning electron microscope.}

$3 \mathrm{~T} 3$ seeded $\left(2.5 \times 10^{5}\right.$ cells/foam $) \mathrm{P}(\mathrm{L} / \mathrm{DL}) \mathrm{LA}-$ PHBV foams were examined under SEM on Days 7 and 14 (Fig. 10). On Day 7, 3T3 cells were significantly high in number both on the top and in the regions somewhat below it [Fig. 10(a)]. However, at a lower level, towards the core of the foam, the number of cells that could be seen in the micrographs decreased significantly. This is probably due to the high thickness of the foam. Since the foams were $6.11 \pm 0.08 \mathrm{~mm}$ thick and seeding was done at the top of the foams, the distance to be traveled by the cells to reach to the central regions by Day 7 was very high. On Day 14 however, more cells could be seen in the middle portions of the foam. The MTS results indicated that there were $1.9 \times 10^{5}$ more cells on Day 14 than on Day 7 $\left(5.6 \times 10^{5}\right.$ and $3.7 \times 10^{5}$, respectively). However, the cells on the micrographs of Day 14, were not as distinguishable as the cells on Day 7 micrographs, even in the micrographs taken from the top view of the foam where the cells were expected to be located most [Fig. 10(b)]. Also, the polymer fibers were not smooth, there seemed to be a deposition on them and the pores seemed to be blocked with some kind of plaque formation [Fig. 10(b)]. These could be interpreted as the large amounts of ECM secreted by 3T3 cells in the regions they reached confluency by Day 14 . Also, by Day 14 the cells started inhabiting the inner portions of the foam (the core regions), secreted lower amounts of ECM because of their lower number, and therefore, the cells were easily identifiable.

\section{Confocal microscopy.}

P(L/DL)LA-PHBV foams seeded with 3 T3 cells at a density of $2.5 \times 10^{5}$ cells / foam were examined with a confocal microscope after staining with Acridine Orange on Day 14 of in vitro culture. Since the foam was too thick, only the top $350 \mu \mathrm{m}$ section could be examined. The observations done by confocal microscopy showed that the cells were distributed in $3 \mathrm{D}$ in the foam. The micrographs showed that the foam was highly porous and the distribution of the cells within the structure was quite homogeneous (Fig. 11). The shapes of the cells indicated the compatibility and resultant spreading of the cells on the polyester carriers.

\section{CONCLUSION}

End stage organ or tissue failure is a common problem in today's world because of our prolonged life-

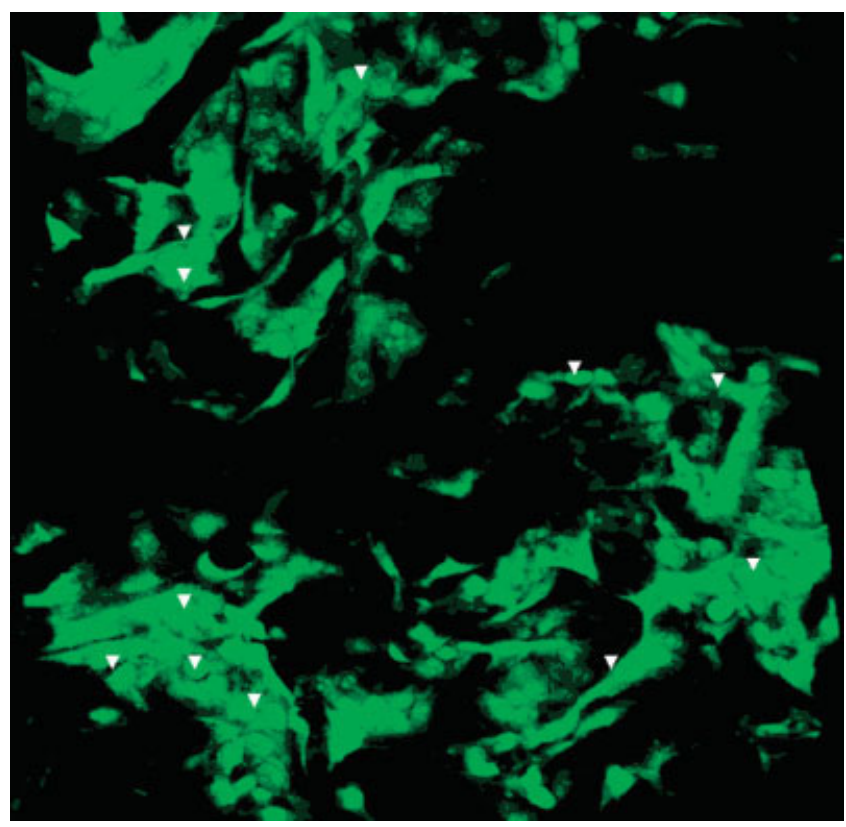

Figure 11. Confocal microscopy of $3 \mathrm{~T} 3$ seeded $\mathrm{P}(\mathrm{L} /$ DL)LA-PHBV foams on Day $14(\times 20$, arrow heads indicate cells). [Color figure can be viewed in the online issue, which is available at www.interscience.wiley.com.] 
span and severe diseases and injuries. In most cases, transplantation from a donor or a nondegradable material or device is used to restore the function of the failed organ. Because of the inherent drawbacks of these treatments (risk of infection, donor tissue scarcity, nonresponsiveness against changing environment, etc.), a new expansion of the biomaterials field, tissue engineering, has started becoming the preferred approach.

In this study, biodegradable and biocompatible polyester carriers of $\mathrm{P}(\mathrm{L} / \mathrm{DL}) \mathrm{LA}-\mathrm{PHBV}$ were tested for the making of cell-material constructs with potential for use in cornea treatment. D407 and 3T3 cells were seeded on the carriers to represent the cells of the epithelium and the stroma of the cornea, respectively, and cultured for 14 days. Characterization of these cells and the carriers was done using various microscopic techniques. The cell number on the carriers was quantified and the functionality of the cells was assessed. Although the polymers used were not ideal substrates for cell attachment, coating of their surface with fibronectin improved significantly the level of cell adhesion, brought it close to that of control TCPS. The MTS results showed that cells seeded on the polymeric carriers attached less but proliferated significantly more than those on the TCPS. The micropatterned surface of the polymeric films allowed alignment of the cells in the earlier days of the culture and formation of D407 cell multilayers in the later days. The microscopic observations of carriers showed that the polymeric foams had the required highly porous structure and pore interconnectivity for their utilization as cell carriers. From the micrographs of the 3T3 cells seeded on the foams, it was seen that the cells were distributed quite uniformly in the foam around the initial seeding site. However, the cell number decreased significantly towards the core of the foam, even on Day 14 probably because of the long distance to be traversed by the cells and also that of nutrients. To obtain a more homogeneous 3D carrier and population of the complete construct with cells, the thickness of the foam needs to be decreased or the foam properties (pore size and porosity) to be improved. Immunohistochemical analysis proved that the cells seeded on the carriers were functional. It can, therefore, be concluded that the P(L/DL)LA-PHBV carriers could be seriously considered as cell carriers in future studies on cornea tissue engineering.

\section{References}

1. Reim M, Kottek A, Schrage N. The cornea surface and wound healing. Prog Retin Eye Res 1997;16:183-225.

2. Ehlers N, Hjortdal J. Corneal thickness: Measurement and implications. Exp Eye Res 2004;78:543-548.
3. Maurice DM. The structure and transparency of the cornea. J Physiol 1957;136:263-286.

4. Hogan MJ, Alvarado JA, Weddel JE. Histology of the Human Eye. Philadelphia: WB Saunders; 1971.

5. Ameen DB, Bishop MF, McMullen T. A lattice model for computing the transmissivity of the cornea and sclera. Biophys J 1998;75:2520-2531.

6. Müller LJ, Pels E, Schurmans LRHM, Vrensen GFJM. A new three dimensional model of the organization of proteoglycans and collagen fibrils in human corneal stroma. Exp Eye Res 2004;78:493-501.

7. Yamada J, Ksander BR, Streilein JW. Cytotoxic T cells play no essential role in acute rejection of orthotopic corneal allografts in mice. Invest Ophthalmol Vis Sci 2001;42:386-392.

8. The Collaborative Corneal Transplantation Studies Research Group. The collaborative corneal transplantation studies (CCTS): Effectiveness of histocompatibility matching in high-risk corneal transplantation. Arch Ophthalmol 1992; 110:1392-1403.

9. Hicks CR, Fitton JH, Chirila TV, Crawford GJ, Constable IJ. Keratoprostheses: Advancing toward a true artificial cornea. Surv Ophthalmol 1997;42:175-189.

10. Chirila TV, Hicks CR, Dalton PD, Vijayasekaran S, Lou $X$, Hong Y, Clayton AB, Ziegelaar BW, Fitton JH, Platten S, Crawford GJ, Constable IJ. Artificial cornea. Prog Polym Sci 1998; 23:447-473.

11. Chirila TV. An overview of the development of artificial corneas with porous skirts and the use of PHEMA for such an application. Biomaterials 2001;22:3311-3317.

12. Hicks CR, Crawford GJ, Tan DT, Snibson GR, Sutton GL, Downie N, Gondhowiardjo TD, Lam DS, Werner L, Apple D, Constable IJ. $\alpha$ Cor cases: Comparative outcomes. Cornea 2003; 22:583-590.

13. Minami Y, Sugihara H, Oono S. Reconstruction of cornea in three-dimensional collagen gel matrix culture. Invest Ophthalmol Vis Sci 1993;34:2316-2324.

14. Germain L, Carrier P, Auger FA, Salesse C, Guerin SL. Can we produce a human corneal equivalent by tissue engineering? Prog Retin Eye Res 2000;19:497-527.

15. Griffith M, Osborne R, Munger R, Xiong X, Doillon CJ, Laycock NL, Hakim M, Song Y, Watsky MA. Functional human corneal equivalents constructed from cell lines. Science 1999;286:2169-2172.

16. Tsai RJF, Ho YS, Chen JK. The effects of fibroblasts on the growth and differentiation of human bulbar conjunctival epithelial cells in an in vitro conjunctival equivalent. Invest Ophthalmol Vis Sci 1994;35:2865-2875.

17. Chena GQ, Wua Q. The application of polyhydroxyalkanoates as tissue engineering materials. Biomaterials 2005;26: 6565-6575.

18. Ferreira BMP, Zavaglia CAC, Duek EAR. Films of poly(L-lactic acid)/poly(hydroxybutyrate-co-hydroxyvalerate) blends: In vitro degradation. Mater Res 2001;4:34-42.

19. Torun Köse G, Kenar H, Hasırcı N, Hasırcı V. Macroporous poly(3-hydroxybutyrate-co-3-hydroxyvalerate) matrices for bone tissue engineering. Biomaterials 2003;24: 1949-1958.

20. Torun Köse G, Korkusuz F, Korkusuz P, Purali N, Özkul A, Hasırc1 V. Bone generation on PHBV matrices: An in vitro study. Biomaterials 2003;24:4999-5007.

21. Kim BS, Mooney DJ. Development of biocompatible synthetic extracellular matrices for tissue engineering. TIBTECH 1998; $16: 224-230$

22. Steele JG, Johnson G, Griesser HJ, Underwood PA. Mechanism of initial attachment of corneal epithelial cells to polymeric surfaces. Biomaterials 1997;18:1541-1551. 
23. Lu L, Nyalakonda K, Kam L, Bizios R, Göpferich A, Mikos AG. Retinal pigment epithelial cell adhesion on novel micropatterned surfaces fabricated from synthetic biodegradable polymers. Biomaterials 2001;22:291-297.

24. Dalton BA, Evans MDM, McFarland GA, Steele JG. Modulation of corneal epithelial stratification by polymer surface topography. J Biomed Mater Res 1999;45:384-394.

25. Pins GD, Toner M, Morgan JD. Microfabrication of an analog of the basal lamina: Biocompatible membranes with complex topographies. FASEB J 2000;14:593-602.

26. Nishida T, Nakagawa $S$, Watanabe $K$, Yamada KM, Otori T, Berman MB. A peptide from fibronectin cell-binding domain inhibits attachment of epithelial cells. Invest Ophthalmol Vis Sci 1988;29:1820-1825.
27. Brunette DM. Spreading and orientation of epithelial cells on grooved substrata. Exp Cell Res 1986;167:203-217.

28. Evans MDM, McFarland GA, Taylor S, Walboomers XF. The response of healing corneal epithelium to grooved polymer surfaces. Biomaterials 2005;26:1703-1711.

29. Ban Y, Dota A, Cooper LJ, Fullwood NJ, Nakamura T, Tsuzuki M, Mochida C, Kinoshita S. Tight junction-related protein expression and distribution in human corneal epithelium. Exp Eye Res 2003;76:663-669.

30. Besseau L, Coulomb B, Lebreton-Decoster C, Giraud-Guille MM. Production of ordered collagen matrices for three-dimensional cell culture. Biomaterials 2002;23:27-36.

31. Rivard $\mathrm{CH}$, Chaput CJ, DesRosiers EA, Yahia LH, Selmani A. Fibroblast seeding and culture in biodegradable porous substrates. J Appl Biomater 1995;6:65-68. 